\title{
Heavy Metal Content in Soils under Different Wastewater Irrigation Patterns in Chihuahua, Mexico
}

\author{
V. M. Maldonado ${ }^{1}$, H. O. Rubio Arias ${ }^{1 *}$, R. Quintana ${ }^{1}$, R.A. Saucedo ${ }^{2}$, M. Gutierrez ${ }^{3}$, J. A. Ortega ${ }^{1}$ and G.V. Nevarez ${ }^{4}$ \\ ${ }^{1}$ College of Zootechnology and Ecology, Autonomous University of Chihuahua, Chihuahua, Mexico \\ ${ }^{2}$ National Institute for Research in Forestry, Agriculture and Animal Production (INIFAP), Chihuahua, Mexico \\ ${ }^{3}$ Missouri State University, Department of Geography, Geology and Planning, Springfield, MO, USA \\ ${ }^{4}$ College of Chemistry, Autonomous University of Chihuahua, Chihuahua, Mexico \\ ${ }^{*}$ Correspondence to Dr. Hector Rubio Arias. E-mail: rubioa1105@hotmail.com
}

Received: 18 September 2008 / Accepted: 05 December 2008 / Published: 31 December 2008

\begin{abstract}
An area near the city of Chihuahua has been traditionally irrigated with wastewater to grow forage crops. It has been hypothesized that metal levels could be found in these soils high enough to cause potential health problems to the population. The objective of this study was to determine heavy metal concentrations in different soils due to irrigation practices. Four soil types were evaluated; a soil with a past and present history of wastewater irrigation (S1), a soil with a history of wastewater irrigation until 2003 (S2), a soil with no irrigation history (S3), and a soil similar to S1 and adjacent to the river where the wastewater is transported (S11). Three soil depths were evaluated; 0-15, 15-30 and 30-50 cm. Consequently, a total of 150 soil samples were analyzed evaluating $\mathrm{pH}, \mathrm{EC}, \mathrm{OM}$ and the following elements; $\mathrm{Na}, \mathrm{K}, \mathrm{Cd}, \mathrm{Pb}, \mathrm{Ni}, \mathrm{Cr}, \mathrm{Cu}$ and $\mathrm{Fe}$. The $\mathrm{pH}(\mathrm{P}=0.000)$ and $\mathrm{EC}(\mathrm{P}=0.000)$ were different for each soil type but no differences were noted for soil depth and the interaction. Maximum $\mathrm{pH}$ levels were noted in $\mathrm{S} 3$ with a value of 8.74 while maximum EC was observed in $\mathrm{S} 1$ with a value of $0.850 \mathrm{dSm}^{-1}$. The OM level was different for soil type $(\mathrm{P}=0.000)$, soil depth $(\mathrm{P}=0.005)$ and the interaction $(\mathrm{P}=0.014)$. S1 and $\mathrm{S} 11$ obtained maximum levels of OM while minimum levels were noted in S3. Maximum OM levels were observed at the 0-15 cm depth followed by the 15-30 $\mathrm{cm}$ depth and finally at the 30-50 cm depth. The highest concentration of metals was as follows: $\mathrm{K}$ in S1 (359.3 $\mathrm{mg}$ $\mathrm{kg}^{-1}$ ); Cd in S1 (4.48 mg kg-1); Pb in S11 (155.83 mg kg-1); Ni in S1 (10.74 mg kg-1); Cu in S1 (51.36 mg kg-1 $)$; B in S3 (41.5 mg kg $\left.{ }^{-1}\right)$; Fe in S3 $\left(20,313.0 \mathrm{mg} \mathrm{kg}^{-1}\right)$, Cr in S3 $\left(44.26 \mathrm{mg} \mathrm{kg}^{-1}\right)$ and $\mathrm{Na}$ in S3 $\left(203.0 \mathrm{mg} \mathrm{kg}^{-1}\right)$. The conclusion is that some metals are present in the soils due to anthropogenic activities but others are present in natural forms.
\end{abstract}

Keywords: Contamination, metals, environment, soil, wastewater, irrigation

\section{Introduction}

Soil is an essential natural resource for support of human life; but with time, its degradation has been constantly increasing due to the deposition of pollutants. The background concentration of metals in virgin soil depends primarily on the bedrock type from which the soil parent material was derived [1]. In addition, anthropogenic inputs may increase metal concentrations, especially in highly industrialized parts of the world producing rare and heavy metals [2]. Until recently, most studies concerning soils related to plant nutrition, with most studies published overseas.

In the particular case of Mexico, one of the environmental problems that require immediate attention is that of metal contaminated soils [3]. Due mainly to industrial activity in recent years, the deposition of a variety of elements in the natural environment has increased. As a result, the concern over water contaminated from human activities has also increased [4]. This concern takes into account a variety of elements referred to in the scientific literature as toxic metals. These metals might be found in waste materials, which in the future will likely be incorporated to the soil resource. The final outcome is an accumulation in the biota, followed by a transfer to humans through the food chain, and causing a potential risk to human health $[5,6]$. According to the USDA [7], the accumulation of heavy metals in soil is toxic for humans as well as animals in general.

In agricultural areas, the addition of metals into the system is primarily due to commercial fertilizer 
applications [8], organic manures [9-11], sediments produced by wastewater [12], irrigation water from industrial and urban areas [13] and atmospheric deposition $[14,15]$. Still, these results are controversial after researchers like Takeda et al. [4] who did not find an increase of elements in soils with the application of soil amendments and Adeli et al. [16] who concluded that broiler litter application did not threaten the ecosystem. Regardless, once in the soil, contaminants may be further transported throughout the soil profiles to groundwater.

Holmgren et al. [17] created a database after analyzing 3,045 soil samples collected from 307 soil series in the United Sates and found differences between land regions. Dudal et al. [18] calculated the influence of some environmental parameters such as residue incorporation, soil temperature and soil events over the quantity of metals that the organic matter could hold. They found that high precipitation events might be responsible for transferring metals held in the soluble organic matter. In other study, Cuevas and Walter [19] concluded that the mobility and bioavailability of heavy metals were factors that depended largely on physical and chemical soil characteristics. Also, the mobility of metals in soil depended not only on its concentration, but it was affected by soil properties, metal properties and environmental factors [20]. The latter factors are related to processes such as adsorption-desorption, occlusion, and precipitation reactions [21]. Therefore, the metals in soil may accumulate in different forms [20] and are the foremost factors impeding the soil microbial process [22].

Ejido Tabalaopa, an area near the city of Chihuahua, has been producing crops and irrigating the land with water from the Chuviscar River. This river, a tributary of the Río Conchos, contains the wastewater of the city of Chihuahua, a city which has grown in terms of industry and includes a very dynamic human population. Several studies like those of Gutierrez et al. [23], Rubio et al. [24], Holguin et al. [25] and Gutierrez and Borrego [26] reported heavy metal concentrations in the water of the Rio Conchos; thus, we expected contamination of the soil resource being irrigated with this water. Yet, in the Tabalaopa area, there is no information concerning the level of soil contamination as an outcome of wastewater irrigation. The objective of this study was to determine the level of contamination from heavy metals, in four types of soil and at three soil depths. The results offer an overall assessment of the contamination degree of the soil due to irrigation with wastewater. It is also an attempt to understand the accumulation of some elements in soil that are not biodegradable and immobile [27] and its possible transfer to the food chain and persistence in the environment as a whole.

\section{Materials and Methods}

The study was conducted during 2006, within Ejido Tabalaopa, an area of 1,094 ha located near the southeastern part of the city of Chihuahua, Mexico. The soil was an Orthid Aridisol with well developed pedogenic horizons, low organic matter in the virgin soil, and dry more than six months a year. An ejido is a community where Mexican law has established that the land must be used collectively or shared. The Ejido Tabalaopa was traditionally used to grow various crops, among them vegetables, until 1996, and using wastewater from the city of Chihuahua to irrigate the land. In 1996, the production of vegetables or any edible crop using wastewater irrigation throughout Mexico was prohibited. At present, this agricultural area is producing different sorts of forage for cattle production and some irrigated land has been abandoned.

Our study area was divided into four zones; a zone having soils with a past and present history of wastewater irrigation (S1), a zone with a history of wastewater irrigation until 2003 (S2), a soil with no irrigation history (S3), and a soil similar to S1 and adjacent to the river where the wastewater is transported (S11). This division was performed using the geographic package Idrisi Kilimanjaro. Using the map included in the package, a total of fifty points were randomly selected resulting in 18 sampling points for S1, 12 sampling points for S11, 10 sampling points for S2 and 10 sampling points for S3. At the Tabalaopa stakeholder's office, using Autocad software, each site was properly located. At each point, three composite soil samples were taken at $0-15,15-30$, and 30-50 cm depths. Hence, fifty-four soil samples were taken in S1, 36 soil samples in S11, 30 soil samples in S2 and 30 soil samples in S3, totaling 150 soil samples.

The soil was collected in plastic bags and transported to the lab. The samples were dried, ground and passed through a $0.355 \mathrm{~mm}$ sieve to remove rocks, roots and any larger particles. The digestion of the soil samples was accomplished with aqua regia following the Analysis protocol of Canada (MAF). The metal concentrations were determined using an Inductively Coupled PlasmaOptical Emission Spectrometry (ICP-OES) Perkin Elmer 2100. The $\mathrm{pH}$ and EC values were determined by a saturated paste using a standard glass electrode for $\mathrm{pH}$ (Hanna) and a conductivity meter for EC (Hanna). The OM was calculated following the standard methodology. Soil texture was calculated using the Boyoucous method. The statistical model included the zone as factor A with four levels (S1, S2, S3 and S11) and the soil profile as factor B with three levels (0-15, 15-30 and 30-50 cm).

\section{Results and Discussion}

Concerning parameter $\mathrm{pH}$, ANOVA showed statistical differences for soil type $(\mathrm{P}=0.000)$ but no differences were found for soil depth and the interaction. It is well known that soil $\mathrm{pH}$ plays an important role in the mobility of metals as in their bioavailability for plants [28, 29]. Figure 1 shows the $\mathrm{pH}$ levels in the four types of soil and its noted that high $\mathrm{pH}$ values with an average of 8.74 were in S3. Minimum pH values were noted in S11 with 7.93 as well as in S1 with 7.80. In S2 soil, the $\mathrm{pH}$ was 8.41. It is also apparent that in the four soil types the $\mathrm{pH}$ was moderately alkaline. Additionally, a tendency of the $\mathrm{pH}$ to increase with depth was observed even though no 
statistical differences were found. This tendency of the $\mathrm{pH}$ to increase below soil profile disagrees with the findings of Ilg et al. [30] which noted that $\mathrm{pH}$ values diminished with increasing depth after phosphorous fertilizations.

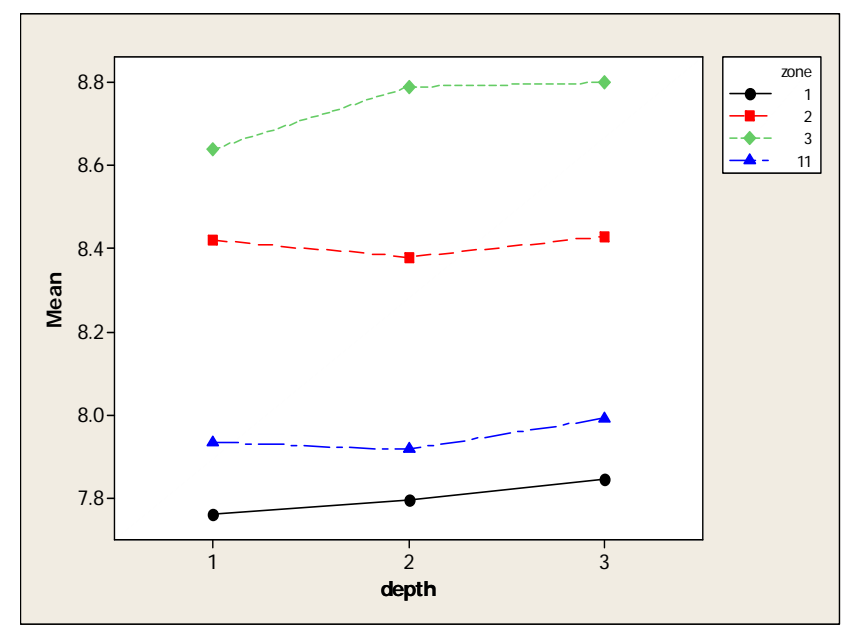

Figure 1: Soil pH in four different types of soil and three depths

The average $\mathrm{pH}$ value in the above soil profile (0-15 $\mathrm{cm})$ was 8.11 followed by the 15-30 depth with 8.14 and profile 30-50 with a $\mathrm{pH}$ average of 8.18 . These results concur with those presented by other researchers [31]. It is generally accepted and well documented that organic matter applications reduce $\mathrm{pH}$ levels [32-34] although Percival [9] did not find this effect in a soil amended with sewage sludge as did Lee et al. [35] who found an increase in the surface soil with manure compost applications. Moreover, He and Singh [36] discovered that organic matter applications reduced the $\mathrm{pH}$ levels while McLaren et al. [37] found a decrease in the $\mathrm{pH}$ levels of four soil types after applications of sewage sludge.

In this study, the minimum $\mathrm{pH}$ levels found in $\mathrm{S} 1$ and S11 may be explained by the fact that organic matter, in its initial phase forms organic acids; but with time, these acids are consumed or transformed and so the $\mathrm{pH}$ tends to increase [38]. Even so, other authors like Lee et al. [35] noted that pig litter applications to a soil in Taiwan tended to increase the $\mathrm{pH}$ in the upper soil horizons. These tests confirmed the results of Shen and Shen [39] who also noted $\mathrm{pH}$ increases in soil with pig compost applications. The results obtained by Adeli et al. [16] found that broiler litter applications increased the $\mathrm{pH}$ values. Interestingly, these researchers also determined that the $\mathrm{pH}$ values decreased in soil receiving only commercial fertilizing applications.

Similar to the results for soil $\mathrm{pH}$, ANOVA detected statistical differences for parameter EC for soil type $(\mathrm{P}=0.000)$ but no differences were found for soil depth or the interaction. In Figure 2, the main effects of the EC values are observed, and it is evident that S11 obtained maximum levels while the minimum values were noted in S3 with a mean of $0.44 \mathrm{dSm}^{-1}$. It is well documented that
OM may increase the levels of EC in soils and the results of this study showed the maximum amount of the OM in S1. Abbaspour et al. [40] reported an increase in levels of EC from 2.3 to $2.7 \mathrm{dSm}^{-1}$ when $50 \mathrm{mmol} \mathrm{NaCl}^{-1}$ was applied to the soil. It is important to acknowledge that the four zones showed acceptable levels of salinity. The literature has reported that high salinity levels may have increased the metal mobility in soils. This process is complete when some cations like $\mathrm{Na}$ and $\mathrm{K}$, substitute the heavy metal cations in the absorption places.

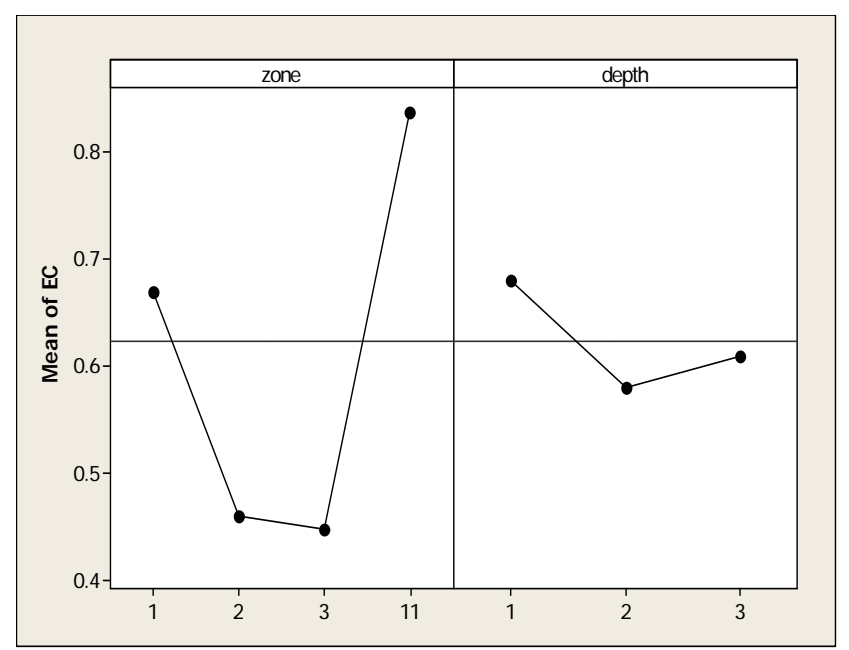

Figure 2: Levels of electrical conductivity $\left(\mathrm{dSm}^{-1}\right)$ in four different types of soil and three depths

Soil OM is a complex and heterogeneous medium that consists of both fractions; the humus fraction (humic acid, fulvic acid, humin) and the particulate fraction, known as particulate organic matter [41]. In this study, there were statistical differences in OM for soil type $(\mathrm{P}=0.000)$, soil depth $(\mathrm{P}=0.005)$ and for the interaction $(\mathrm{P}=0.014)$. OM is critical because of its tendency to form metal composite OM-metals [42, 43]. Previous studies have demonstrated that $\mathrm{OM}$ contains functional groups like $-\mathrm{COOH}$ and $-\mathrm{OH}$ that serve as a union of OM with metals [44, 45]. Other studies have exemplified the increment of OM levels in soils with the application of organic matter [46-49], resulting in the improvement of the soil structure [50]. Figure 3 identifies the different levels of OM, according to soil type. As expected, S1 and S11 obtained maximum levels of OM with means of 3.31 and $2.19 \mathrm{mg} \mathrm{kg}^{-1}$ in comparison with S2 and S3, which presented means of 1.52 and $0.89 \mathrm{mg} \mathrm{kg}^{-1}$, respectively. For S1 and S11, a negative linear tendency of OM content as affected by soil profile was clear. The maximum amount of OM was found in the $0-15 \mathrm{~cm}$ soil profile with a mean of $2.65 \mathrm{mg}$ $\mathrm{kg}^{-1}$, followed by the soil profile $15-30 \mathrm{~cm}$ with an OM mean of $2.21 \mathrm{mg} \mathrm{kg}^{-1}$, and finally, the soil profile $30-50$ $\mathrm{cm}$ with a mean of $1.75 \mathrm{mg} \mathrm{kg}^{-1}$. It is essential to point out that OM has proven the most important soil component controlling the sorption and desorption of metals, being most clear this effect in the metal cadmium [51]. 


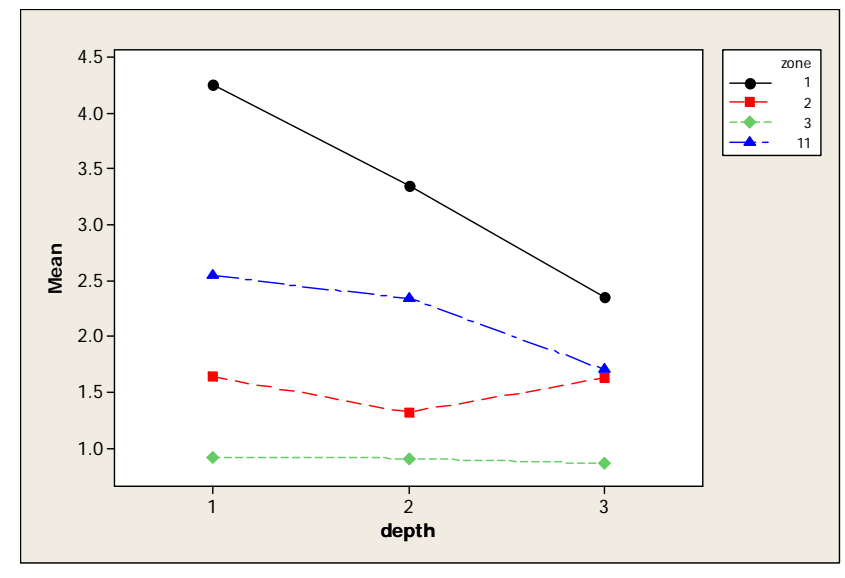

Figure 3: Soil OM in four different types of soil and three depths

The $\mathrm{K}$ concentration was different for soil type $(\mathrm{P}=0.000)$ and no differences were found for soil depth or the interaction. Maximum K levels were noted in S1 with $359.3 \mathrm{mg} \mathrm{kg}^{-1}$ and S11 with $349.2 \mathrm{mg} \mathrm{kg}^{-1}$ when compared to levels of $321.8 \mathrm{mg} \mathrm{kg}^{-1}$ for S2 and $331.0 \mathrm{mg} \mathrm{kg}^{-1}$ for S3. Even though there were no statistical differences in soil depth, a decrease in $\mathrm{K}$ was observed in the way the soil horizon was lower. Lee et al. [35] in a study with pink compost applications, found the maximum $\mathrm{K}$ concentration in the higher soil horizons. The results of these authors agree with those of Bulluck et al. [52] who recorded $\mathrm{K}$ increments in the above soil profile after bovine cattle manure applications. In this research, soils S1 and S11 are obviously receiving this element in a dynamic form, hence their presence in the above strata.

The amount of $\mathrm{Na}$ was different for soil type $(\mathrm{P}=0.000)$ but no differences were noted for soil depth or the interaction. The highest level of this element was found in S3 with $203.0 \mathrm{mg} \mathrm{kg}$-1 while the lowest amount was noted in S1 with $197.6 \mathrm{mg} \mathrm{kg}^{-1}$ and S11 with 197.8 $\mathrm{mg} \mathrm{kg}^{-1}$. The Na levels in soil depth were similar and no tendency was noted, obtaining $199.7 \mathrm{mg} \mathrm{kg}^{-1}$ in the $0-15$ cm depth, $199.6 \mathrm{mg} \mathrm{kg}^{-1}$ in the $15-30 \mathrm{~cm}$ depth and 198.9 $\mathrm{mg} \mathrm{kg}^{-1}$ in $30-50 \mathrm{~cm}$ soil profile.

The levels of $\mathrm{Cd}$ were different for soil type $(\mathrm{P}=0.000)$ but not differences were noted for soil depth and the interaction. The lowest levels of Cd were in S2 with $1.62 \mathrm{mg} \mathrm{kg}^{-1}$ while maximum levels were obtained in S1 (4.88 $\mathrm{mg} \mathrm{kg}^{-1}$ ) and S3 (4.41 $\mathrm{mg} \mathrm{kg}^{-1}$ ). The Cd level found in S3 which identified a soil under natural condition is higher than the results presented by Rubio et al. [53] in a study of natural soil also in the state of Chihuahua. As well, the results obtained in the present study were higher than those presented in soils of India with levels of 0.37 $\mathrm{mg} \mathrm{kg}^{-1}$ [54], England with $0.8 \mathrm{mg} \mathrm{kg}^{-1}$ [55], China with $0.07 \mathrm{mg} \mathrm{kg}^{-1}$ [56], Spain with amounts in the range of 0.4$0.8 \mathrm{mg} \mathrm{kg}^{-1}$ [57], Germany with levels in a range of 0.6-1$4 \mathrm{mg} \mathrm{kg}^{-1}$ [58] and Japan with $0.41 \mathrm{mg} \mathrm{kg}^{-1}$ [59]. Although no statistical differences were noted for soil depth, a slight decrement of $\mathrm{Cd}$ amounts in lower soil profiles was observed. These results may be explained by the fact that $\mathrm{Cd}$ is more soluble and mobile in soil when compared with other elements [60, 61]. Plus, OM levels in soil are the most important component that controls the absorption and desorption processes [51]. Yet, researchers like McLaren et al. [62] reported that Cd was the element less mobile when compared to other elements like $\mathrm{Cr}, \mathrm{Cu}$ and $\mathrm{Pb}$. These researchers explained their results by which OM influences the soil environment. Our original hypothesis was that differences will be evident in S1 and S3; one with wastewater irrigation and the other natural soil without any irrigation background. It was surprising that both soils presented similar levels of $\mathrm{Cd}$. So, it is assumed that the $\mathrm{Cd}$ in the natural soil is coming from natural sources or due to anthropogenic pollution from sources other than irrigation. Near the study area, one of the larger smelter/refinery complexes in the world, named Avalos, operated for approximately 90 until the past several years when it ceased to operate, and we assumed that the amount of $\mathrm{Pb}$ in $\mathrm{S} 3$ might be explained by that fact. To date, there are no geological studies to acknowledge the Cd levels in the zone; however, the results of this study are higher than other results overseas $\left(<1.0 \mathrm{mg} \mathrm{kg}^{-1}\right)$ for a mineral soil [63].

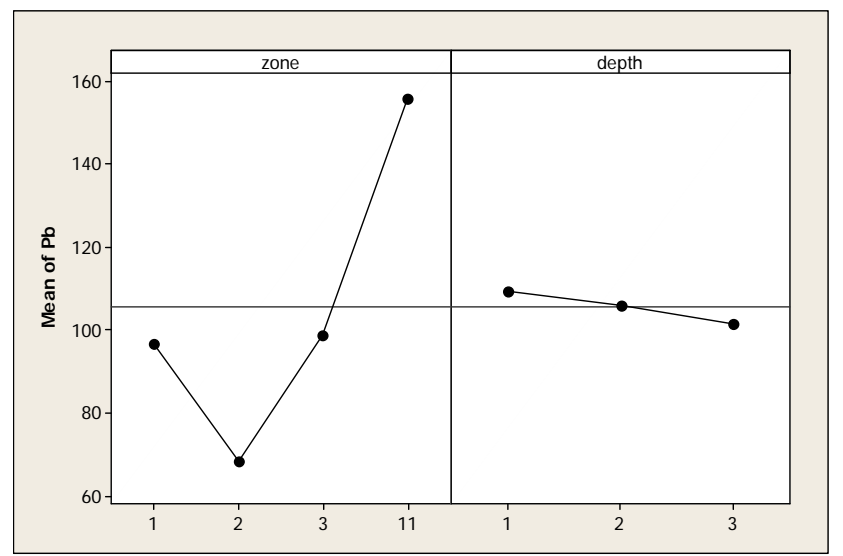

Figure 4: Soil $\mathrm{Pb}$ levels in four different types of soil and three depths

Figure 4 shows the main effects of $\mathrm{Pb}$ in the four soil types and in the three depths. ANOVA detected statistical differences for soil type but not differences for soil depth and the interaction. In Figure 4, it is evident that the greatest amount of $\mathrm{Pb}$ was in S11 with a mean of 155.83 $\mathrm{mg} \mathrm{kg}{ }^{-1}$. Contrary to our original hypothesis, S2 obtained the lowest $\mathrm{Pb}$ concentration with a mean of $68.47 \mathrm{mg} \mathrm{kg}^{-1}$, followed by S3 with $98.75 \mathrm{mg} \mathrm{kg}{ }^{-1}$. The results in S2 might be explained by the lixiviation of the element in soil due to precipitation events after wastewater irrigation ceased [64, 65]. The presence of $\mathrm{Pb}$ in S3 may be explained by the background of the smelter/refinery complex (Avalos); in fact, Ornelas et al. [66] reported values of $400 \mathrm{ppm}$ of this element in the vicinity of the complex. We must make clear that in 1994, Mexico produced 163,700 tons of lead [67] and was considered at the top of the world's countries in lead production and the State of Chihuahua was considered the major producer in Mexico [68]. Studies of $\mathrm{Pb}$ pollution have reported 
accumulation of this metal in soils even far from the source [69]. For instance, Billett et al. [70] found significant increments in forestry soils where the contamination source was about $120 \mathrm{~km}$ away. Ultimately, the levels of $\mathrm{Pb}$ reported in this study must be regarded as high, when considering that a normal soil contains approximately $10 \mathrm{mg} \mathrm{kg}^{-1}$, but some contaminated soils may contain $1,000 \mathrm{mg} \mathrm{kg}^{-1}$ [71]. A tendency of the $\mathrm{Pb}$ levels to decrease with depth was observed. These results support the hypothesis proposed by Miller and Friedland [72] which established that colloidal particles are of great importance in the $\mathrm{Pb}$ movement from the upper to lower soil horizons. This study has noted that all levels of OM were higher in the upper soil horizon and possibly, the levels in the lower soil horizons are a result of this movement [73]. The concentrations obtained in this study are higher than those reported by Rubio et al. [53] in Chihuahua, Mexico; likewise, in soils of India with 10.4 $\mathrm{mg} \mathrm{kg}^{-1}$ [54] and Japan with $21 \mathrm{mg} \mathrm{kg}^{-1}$ [59]. It must be known that high levels of $\mathrm{Pb}$ in soils may produce a significant decrement on the enzymatic activity, meaning that this metal has a toxic effect in the different biochemical reaction occurring in the soil environment [22, 74-76]. Accordingly, plant productivity and microbiological communities in the soil environment decrease [77].

In the particular case of $\mathrm{Ni}$, ANOVA detected statistical differences by soil type $(\mathrm{P}=0.000)$ but no differences were found for soil depth or the interaction (Figure 5). Again, the highest level of Ni was observed in the $30-50 \mathrm{~cm}$ depth $\left(9.81 \mathrm{mg} \mathrm{kg}^{-1}\right.$ ) with the exception of soil S3. These results are consistent with those of McLaren et al. [62] who found that about $57 \%$ of $\mathrm{Ni}$ applications were lixiviated from upper soil horizons to lower soil horizons. The lowest $\mathrm{Ni}$ concentrations were detected in S2 with a mean of $7.45 \mathrm{mg} \mathrm{kg}^{-1}$ and S11 with a mean of $8.86 \mathrm{mg} \mathrm{kg}^{-1}$.

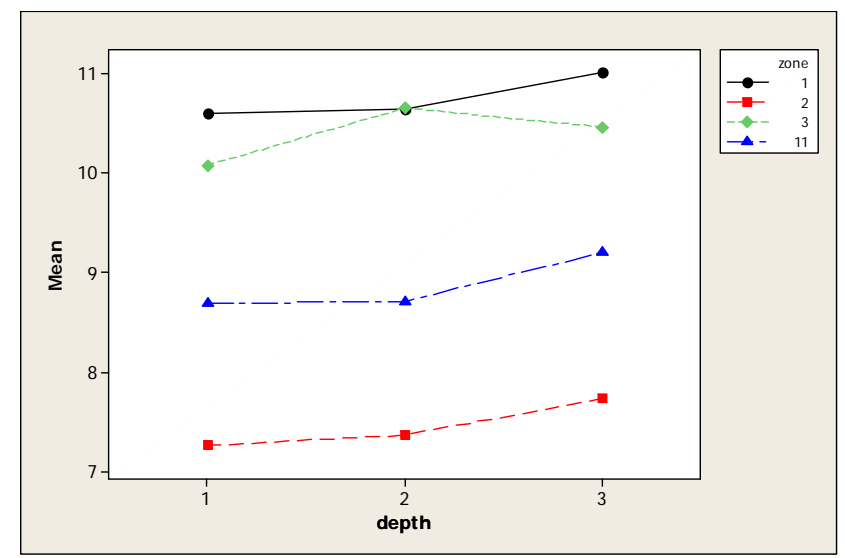

Figure 5: Soil Ni levels in four different types of soil and three depths

The $\mathrm{Cr}$ level was superior in S3 with a mean of 44.27 $\mathrm{mg} \mathrm{kg}^{-1}$ while the lowest values were noted in S2 with a mean of $37.10 \mathrm{mg} \mathrm{kg}^{-1}$. Intermediate values were observed in S1 with $40.06 \mathrm{mg} \mathrm{kg}^{-1}$ and S11 with $38.74 \mathrm{mg} \mathrm{kg}^{-1}$. It was clear that Cr has a tendency to be increased with depth.

Contrary to the findings of $\mathrm{Ni}$ and $\mathrm{Cr}$, the lowest concentrations of $\mathrm{Cu}$ were detected in S3 and S2 with means of 7.17 and $10.6 \mathrm{mg} \mathrm{kg}^{-1}$, respectively, while maximum values were noted in S1 with $51.35 \mathrm{mg} \mathrm{kg}^{-1}$ and S11 with $38.61 \mathrm{mg} \mathrm{kg}^{-1}$. Li et al. [78] reported that levels of $\mathrm{Cu}$ in soil above $10-25 \mathrm{mg} \mathrm{kg}^{-1}$ might reduce plant productivity. Thus, S1 and S11 might prove toxic for plant production. Besides, the $\mathrm{Cu}$ concentration has a tendency to increase with depth. This tendency agrees with a report by $\mathrm{Hu}$ et al. [79] that found $\mathrm{Cu}$ concentrations in a range of 0.01 to $0.26 \mathrm{mg} \mathrm{L}^{-1}$ in the $20 \mathrm{~cm}$ depth and of 0.01 to $0.33 \mathrm{mg} \mathrm{L}^{-1}$ in the $50 \mathrm{~cm}$ depth. In other study, McLaren et al. [62] mentioned that $\mathrm{Cu}$ soil applications have certain mobility from upper horizons to lower horizons. These authors specified that $\mathrm{Cu}, \mathrm{Cr}$ and $\mathrm{Pb}$ had a mobility of $35 \%$ from the above soil profile to deeper soil profiles. These results also agree with Dowdy et al. [80] which speculated that metals could be transported from upper zones to lower zones through macropores present in soils. For this reason, most of the metals evaluated in this research have a tendency to increase in lower horizons and coincide with other studies previously reported [81, 82].

Fe level was different due to soil type $(\mathrm{P}=0.000)$ but no differences were found for soil depth or the interaction. The highest levels of Fe were noted in S3 with 20,313.0 $\mathrm{mg} \mathrm{kg}^{-1}$ while the lowest amount was observed in S2 with a mean of $17,865.33 \mathrm{mg} \mathrm{kg}$. As noted in the other evaluated metals, the levels of $\mathrm{Fe}$ also increased with depth. The B concentration was different due to soil type $(\mathrm{P}=0.000)$ but no differences were found for soil depth and the interaction. The S3 showed the highest amount of this element with a mean of $41.47 \mathrm{mg} \mathrm{kg}^{-1}$, while the lower amount was detected in S2 with a mean of $14.70 \mathrm{mg} \mathrm{kg}^{-1}$. In contract with other elements, B levels were superior in the upper soil horizon.

\section{Conclusions and Recommendations}

The analysis demonstrated that among the variables, soil type was the only showing a statistical difference, which indicates that the resulting concentrations can be largely explained by the type of irrigation the soil had at the time. It was noted that concentrations of nickel, chromium, copper, iron and boron concentrated in deeper soil layers while potassium, sodium, cadmium, and lead showed the opposite effect.

In areas where elements were expected to be present in lesser concentrations as in the case of S3, the opposite effect was observed with respect to S1, S11 and S2. Instead, sodium, cadmium, chrome, iron and boron, showed higher concentrations in S3, which is contradictory to the established hypothesis for being an area lacking in irrigation. This may be explained by natural concentrations of said elements or, in the case of cadmium, by airborne contamination from the Avalos smelter. It was also noted that organic material is an important variable and that it can influence the mobility of 
metals in those areas where high concentrations such as S1 and S11, which coincide with constant irrigation. Clearly, the area has been constantly exposed to certain health hazardous metals. More attention is recommended, even though at this time a wastewater treatment plant has been built and part treated water is used to irrigate the crops. Still, residual water is used for forage irrigation, and this practice could generate illnesses in the population near the study area.

Acknowledgments: We are deeply grateful with the National Committee of Science and Technology of Mexico (CONACYT) which provided a grant for carrying out the research reported here.

\section{References}

1. Donahue, R. L.; Miller, R. W.; Shickluna, J. C.: Soils, and introduction to soils and plant growth. Fifth edition. Prentice, Hall, Inc., Englewood Cliffs, New Jersey, 1983; pp. 1-45.

2. USGS, United States Geological Survey. Statistics and information. 2008. Available in: http://mineral.usgs.gov/minerals/pubs/commodity. Accessed July 2008.

3. INE, Instituto Nacional de Estadística. Dirección de investigación en residuos y suelos contaminados. 2004. Available in: www.ine.gob.mx.

4. Takeda. A.; Tsukada, H.; Nanzyo, M.; Takaku, Y.; Uemura, T.; Hisamatsu, S.; Inaba, J.: Effect of long-term fertilizer application on the concentration and solubility of major and trace elements in a cultivated andisol. $J$. Soil Science. Plant Nutr. 2005, 51, 2, 251-260.

5. Arnt, J.; Rudnitski, K.; Schmidt, B.; Speelman, L.; Nobouphasavanh, S.: Environmental risk assessment of spraying landfill leachate on the Guelph Turfgrass Institute (GTI) site: Focus on $\mathrm{Pb}$ and As. Earth and Atmosphere Field Camp 87-411. University of Guelph, Guelph, ON. 1997.

6. Franklin, R. E.; Duis, L.; Smith, B. R.; Brown, R; Toler, J. E.: Elemental concentration in soils of south Carolina. J. Soil Science. 2003, 168, 280-291.

7. USDA, United States Department of Agriculture. Heavy metals soil contamination. 2000. Available in; www.soil.usda..gov/sqi/files/u03d.pdf. Acceded March 8, 2006.

8. Gray, C. W.; McLaren, R. G.; Roberts, A.H.C.; Condron, L.M. Sorption and desorption of cadmium from New Zealand soil: effect of $\mathrm{pH}$ and contact time. Australian Journal of Soil Research. 1998, 36, 199216.

9. Percival, H. J.: Soil and soil solution chemistry of a New Zealand pasture soil amended with heavy metalcontaining sewage sludge. Australian Journal of Soil Research. 2003, 41, 1-17.

10. Payne, G. G.; Martens, D. C.; Winarko, C.; Perera, N. F.: Availability and form of copper in three soils following eight annual applications of copper.enriched swine manure. J. Environ. Quality. 1988, 17, 740-746.

11. Han, F. X.; Kingery, W. L.; Selim, H. M.; Derard, P. D.: Accumulation of heavy metals in a long-term poultry waste-amended soil. Soil Science. 2000, 165, 260-268.

12. Assadian, N. W.; Vogel, Ch.; Sheng, Z.; Figueroa, U. V.; Palomo, M.: Heavy metal distribution in open canals and drains in the upper Rio Grande Basin. Soil and Sediment Contamination. 2003, 12, 3, 305-323.

13. Adriano, D. C.: Trace elements on terrestrial environments. $2^{\text {nd }}$ Ed., Springer-Verlag, New York, Berlin, and Heidelberg. 2001.

14. Blake, L.; Goulding, K. W. T.: Effects of atmospheric deposition, soil $\mathrm{pH}$ and acidification on heavy metals contents in soils and vegetation of semi-natural ecosystems at Rothamsted Experimental Station, UK. Plant Soil. 2002, 240, 235-251.

15. Senesi, G. S.; Baldassarre, G.; Senesi, N.; Radina, R.: Trace elements inputs into soils by anthropogenic activities and implications for human health. Chemosphere. 1999, 39, 343-377.

16. Adeli, A.; Sistani, K. R.; Tewolde, H.; Rowe, D. E.: Broiler litter application effects on selected trace elements under conventional and no-till system. Soil Science. 2007, 172, 5, 349-365.

17. Holmgren, G.; Meyer, M. W.; Chaney, R. L.; Daniels, R.B. Cadmium, lead, zinc, copper and nickel in agricultural soils of the United States of America. J. of Environ. Quality. 1993, 22, 335-348.

18. Dudal, Y.; Sévenier, G.; Dupont, L.; Guillon, E. Fate of the metal-binding soluble organic matter throughout a soil profile. J. Soil Science. 2005, 170, 707-715.

19. Cuevas, G.; Walter, I.: Metales pesados en maíz (Zea maiz L) cultivado en un suelo enmendado con diferentes dosis de composta de lodo residual. Rev. Internacional de contaminación ambiental. 2004, 5, $19-21$

20. He, Z. L.; Zhang, M. K.; Calvert, D. V.; Stofella, P. J.; Yang, X. E.; Yu, S.: Transporte de metales pesados en el escurrimiento superficial de campos de vegetales y cítricos. J. Soil Science. Soil \& Water Management \& Conservation. 2004, 68, 1662-1669.

21. Li, J.; Rate, A. W.; Gilkes, R. J.: Fractionation of trace elements in some non-agricultural Australian soils. Australian Journal of Soil Research. 2003, 1389-1402.

22. Stuczynskiel, T. I.; McCarty, G. W.; Siebielec, G.: Response of soil microbiological activities to cadmium, lead, and zinc salt amendments. J. of Environ. Quality. 2003, 32, 1346-1355.

23. Gutierrez, L. R.; Rubio-Arias, H.; Quintana, R.; Ortega, J. A.; Gutierrez, M.: Heavy metals in water of the San Pedro River in Chihuahua, Mexico and its potential health risk. International Journal of Environmental Research and Public Health. 2008, 5, 2, 91-98. 
24. Rubio, A. H.; Wood, K.; Alanis, H. E.: Water pollution in the Rio Conchos of Northern Mexico. Develpment and application of computer techniques to Environmental Studies. Editores; G. Latini, G. Passerini y C.A. Brebbia. Witpress. 2004, 167-176.

25. Holguín, C.; Rubio, A. H.; Olave, M. A.; Saucedo, T. R.; Gutiérrez, M.; Bautista, R.: Calidad del agua del Río Conchos en la región de Ojinaga, Chihuahua: Parámetros fisicoquímicos, metales y metaloides. Universidad y Ciencia. 2006, 22, 1, 51-63.

26. Gutierrez, M.; Borrego, P.: Water quality assessment of the Rio Conchos, Chihuahua, Mexico. Environmental International. 1999, 25, 5, 573-583.

27. Mermut, A. R.; Jain, J. C.; Song, L.; Kerrich, R.; Kozak, L.; Jana, S.: Trace element concentration of selected soils and fertilizers in Saskatchewan. Canadian Journal of Environ. Quality. 1996, 25, 845853.

28. Gambrell, R. P.: Trace and toxic metals in wetlands: A review. J. Environ Quality. 1994, 23, 883-891.

29. Sparling, D. W.; Lowe, T. P.: Metal concentrations in aquatic macrophytes as influenced by soil and acidification. Water Air Soil Pollut. 1998, 108, 203221.

30. Ilg, K.; Siemens, J.; Kaupenjohann, M.: Colloidal and dissolved phosphorous in sandy soils as affected by phosphorous saturation. J. of Environ. Quality. 2005, 34, 926-935.

31. Smith, L. M.; Hall, K J.; Lavkulich, L. M.; Schreier, H. 2007. Trace metals concentrations in an intensive agricultural watershed in British Columbia, Canada. Journal of the American Water Resources Association. 2007, 43, 6, 1455-1467.

32. Chang, C.; Sommerfeldt, T. G.; Entz, T.: Rates of Soil Chemical Changes with 11 Annual Applications of Cattle Feedlot Manure. Canadian Journal of Soil Science. 1990, 70, 673-681.

33. Couillard, D.; Li, J. F.: Assessment of Manure Application Effects Upon the Runoff Water Quality by Algal Assays and Chemical Analyses. Environmental Pollution. 1993, 80, 3, 273-279.

34. Karthikeyan, K. G.; Kalbasi, M.; Miller, P. S.: Nitrogen and Solution Dynamics in Soils Receiving Chemically Treated Dairy Manure. Transactions of the ASAE. 2005, 48, 601-610.

35. Lee, Ch. H.; Wu, M. Y.; Asio, V. B.; Chen, Z. S. Using a soil quality index to assess the effects of applying swine manure compost on soil quality under a crop rotation system in Taiwan. Soil Science. 2006, $171,3,210-222$.

36. He, Q. B.; Singh, B. R.: Effect of organic matter on the distribution, extractability and uptake of $\mathrm{Cd}$ in soils. J. Soil Science. 1993, 44, 641-650.

37. McLaren, R. G.; Clucas, L. M.; Taylor, M. D.; Hendry, T.: Leaching of macronutrients and metals form undisturbed soils treated with metal-spiked sewage sludge. 2. Leaching of metals. Australian Journal of Soil Research. 2004, 42, 459-471.
38. Simandi, P.; Takayanagi, M.; Inubushi, K.: Changes in the $\mathrm{pH}$ of two different composts are dependent on the production of organic acids. Soil Science and Plant Nutrition. 2005, 51, 5, 771-774.

39. Shen, Q. R.; Shen, Z. G.: Effects of pigs manure and wheat straw on growth of mungbean seedlings grown in aluminum toxic soil. Bioresour. Technol. 2001, 76, 235-240.

40. Abbaspour, A.; Kalbasi, M.; Hajrasuliha, S.; Golchin, A. Effects of plant residue and salinity on factions of Cadmium and Lead in three soils. Soil and Sediment Contamination. 2007, 16, 6, 539-556.

41. Elliott, E. T.: Rationale for developing bioindicators of soil health. In Pankhurst CE, Doube BM, Gupta VVSR, eds, Biological Indicators of Soil Health. Commonwealth Agricultural Bureau, International, Wallingford, Oxon, UK, 1997, 49-78.

42. Halim, M.; Conte, P.; Piccolo, A. Potential availability of heavy metals to phytoextraction from contaminated soils induced exogenous humic substances. Chemosphere. 2003, 52, 265-275.

43. Almas, A. R.; Mc Bride, M. B.; Singh, B. R.: Solubility and lability of cadmium and zinc in two soils treated with organic matter. Soil Science. 2000, 165, 250-259.

44. Heredia, W.; Peirano, P.; Borie, G.; Aguilera, M.: Soil organic matter-metal interactions in Chilean volcanic soils under different agronomic management. Commun Soil Sd Plant Anal. 2002, 33, 2083-2099.

45. Weng, L. P.; Temminghoff, E. J. M.; Lofts, S.; Tipping, E.; Van Riemsdijk, W. H.: Complexation with dissolved organic matter and solubility control of heavy metals in a sandy soil. Environ Sd Technol. 2002, 36, 4804-4810.

46. Warman, P. R. 2005. Soil fertility, yield and nutrient contents of vegetable crops after 12 years of compost amendments. Biological Agriculture and Horticulture. 2005, 23, 85-96.

47. Crecchio, C.; Curci, M.; Mininni, R.; Ricciuti, P.; Ruggiero, P.: Short-term effects of municipal soil waste compost ammendments on soil carbon and nitrogen content, some enzyme activities and genetic diversity. Biology and Fertility of Soils. 2001, 34, 311-318.

48. Garcia-Gill, J. C.; Plaza, C.; Soler-Rovira, P.; Polo, A.: Long-term effect of municipal waste compost application on soil enzyme activities and microbial biomass. Soil Biology and Biochemistry. 2000, 32, 1907-1913.

49. Gagnon, B.; Lalande, R.; Fahmy, S. Organic matter and aggregation in a degraded potato soil as affected by raw and composted pulp residue. Biology and Fertility of Soil. 2001, 34, 441-447.

50. Shepherd, M. A.; Harrison, R.; Webb, J.: Managing soil organic matter - implications for soil structure on organic farms. Soil Use and Management. 2002, 18, 284-292.

51. Gray, C. W.; McLaren, R. G.; Roberts, A. H. C.; Condron, L. M.: The effect of long-term phosphatic 
fertilizer applications on the amounts and forms of cadmium in soils under pasture in New Zealand. Nutrient Cycling in Agroecosystems. 1999, 54, 267277.

52. Bulluck, III. L. R.; Brosius, M.; Evanylo, G. K.; Ristaino, J. B.: Organic and synthetic fertility amendments influence soil microbial physical and chemical properties on organic and conventional farms. Appl. Soil Ecol. 2002, 19, 147-160.

53. Rubio, A. H.; Saucedo, T. R.; Bautista, R.; Wood, K.; Holguin, C.; Jimenez, J. Are crop and range land being contaminated with cadmium and lead in sediments transported by wind from an adjacent contaminated shallow lake? Geo-environment and Landscape Evolution II. Ed. J. F. Martin.Duque, C. A, Brebbia, D. E. Emmanouloudis y U. Mander. Witpress. 2006, 135-141.

54. Roychowdhury, T.; Uchino, T.; Tokunaka, H.; Abd Ando, M.: Arsenic and other heavy metals in soils from an arsenic-affected area of West Bengal, India. Chemosphere. 2002, 49, 6:605-618.

55. McGrath, S. P.; Loveland, P. J.: Heavy metals in soils. In the soil geochemical atlas of England. B.J. Alloway (ed.) Blackie Academic and Professional, Glasgow, Scotland. 1992.

56. Wang, Y.; Wei, F. S. (eds.): Soil environmental element chemistry. Chinese Environmental Science Press, Peking, People's Republic of China. 1995.

57. Gil, C.; Boluda, R.; Ramos, J. Determination and evaluation of cadmium, lead and nickel in greenhouse soils of Almeria (Spain). Chemosphere. 2004, 55, 7, 1027-1034.

58. Munch, D.: Soil contamination beneath asphalt roads by polynuclear aromatic hydrocarbons zinc, lead and cadmium. Science of the Total Environments. 1992, 126, 1-2, 49-60.

59. Akira, T.; Hirofumi, T.; Masami, N.; Yuichi, T.; Toyokazu, U.; Shunñichi, H.; Jiro, I. Effect of longterm fertilizer application on the concentration and solubility of major and trace elements in a cultivated andisol. Soil Sci. Plan. Nutr. 2005, 51, 2, 251-260.

60. Chen, Z. S.; Lee, G. J.; Liu, J .C. 2000. The effects of chemical remediation treatments on the extractability and speciation of cadmium and lead in contaminated soils. Chemosphere. 2000, 41, 235-242.

61. Massadeh, A. M.; Tahat, M.; Jaradat, Q. M.; AlMomani, I. F.: Lead and cadmium contamination in roadside soils in Irbid city, Jordan. A case study. Soil Sediment Contamination. 2004, 13, 347-359.

62. McLaren, R. G.; Clucas, L. M.; Taylor, M. D.: Leaching of macronutrients and metals from undisturbed soils treated with metal-spiked sewage sludge. 3. Distribution of residual metals. Australian Journal of Soil Research. 2005, 43, 159-170.

63. Traina, S. J.: The environmental chemistry of cadmium. In. M.J. McLaughlin y B.R. Singh (ed) Cadmium in soil and plants. Lower, Academic Publ. Dordrecht, The Netherlands. 1999, 11-37.
64. Stevens, D. P.; McLaughlin, M. J.; Heinrich, T. 2003: Determining toxicity of lead and zinc runoff in soils: Salinity effects on metal partitioning and on phytotoxicity. Environ Toxicol Chem. 2003, 22, 20173024.

65. Bongers M.; Rusch, B.; Van Gestel, C. A. M.: The effect of counterion and percolation on the toxicity of lead for the springtail Folsomia candida in soil. Environ Toxicol Chem. 2004, 23,195-199.

66. Ornelas, H. M.; Sanin, A. L. H.; Diaz-Barriga, F.; Reza, L. S. A.; Romieu, I. 2007: Evaluacion de riesgo de intoxicación por plomo en la zona urbana aledaña a una fundidora en Chihuahua, Mexico. Tecnociencia, Chihuahua. 2007, 1, 1, 26-35.

67. FRD, Federal Research Division, Library of the Congress. Mexico - A country study. 1996. Energy and Mining. Edited by Tim L. Merrill and Ramon Miró. http://www.country-data.com/cgi-bin/query/r8677.html.

68. Gobierno del Estado de Chihuahua. Informe de Gobierno. Chihuahua, Chihuahua, Mexico. 2004.

69. Tyler, G. Heavy metals pollute nature-may reduce productivity. Ambio. 1972, 1, 52-59.

70. Billett, M. F.; Fitzpatrick, E. A.; Cresser, M. S.: Long-term changes in the $\mathrm{Cu}, \mathrm{Pb}$, and $\mathrm{Zn}$ content of forest soils organic horizons form North-East Scotland. Water Air Soil Pollut. 1991, 59, 179-191.

71. Pichtel, J.; Kuroiwa, K.; Sawyerr, H.: Distribution of $\mathrm{Pb}, \mathrm{Cd}$, and $\mathrm{Ba}$ in soils and plants of two contaminated sites. Environ. Pollut. 2000, 110, 171-178.

72. Miller, E. K.; Friedland, A. J.: Lead migration in forest soils: Response to changing atmospheric inputs. Environ. Sci. Technol. 1994, 28, 662-669.

73. McBride, M. B.; Richards, B.; Steenhuis, T.; Russo, J. J.; Sauve, S. Biobility and solubility of toxic metals and nutrients in soil fifteen years after sludge application. Soil Science. 1997, 162, 487-500.

74. Tejada, M.; Hernandez, M. T.; Garcia, C.: Application of two organic wastes in a soil polluted by lead; Effects on the soil enzymatic activities. $J$. of Environ. Quality. 2007, 36,216-225.

75. Chlopecka, A.; Bacon, J. R.; Wilson, M. J.; Kay, J.: Forms of Cadmium, lead, and zinc in contaminated soils from southwest Poland. J. of Environ. Quality. 1996, 25, 69-79.

76. Marzadori, C.; Ciaviatta, C.; Montecchio, D.; Gressa, C. Effects of lead pollution on different soil enzyme activities. Biol. Fertil. Soils. 1996, 22, 53-58.

77. Guiller, K. E.; Witter, E.; McGrath, S. P.: Toxicity of heavy metals to microorganisms and microbial processes in agricultural soils. A review. Soil Biol. Biochem. 1998, 30, 1389-1414.

78. Li, G. C.; Wang, Y. P.; Chang, J. M.: Heavy metals concentrations in soils of Taiwan. Publication by the Environmental Protection Administration (EPA) of Taiwan. Taipei, Taiwan. 1987.

79. Hu, N.; Luo, Y.; Longhua, W.; Song, J.: A field lysimeter study of heavy metals movement down to the profile soils with a multiple metal pollution during 
chelate-enhanced phytoremediation. International Journal of Phytoremediation. 2007, 9, 4-6, 257-269.

80. Dowdy, R. H.; Latterell, J. J.; Hinesly, T. D.; Grossman, R. B.; Sullivan, D. L.: Trace elements movement in an Aeric Ochraquaf following 14 years of annual sludge applications. J. of Environ. Quality. 1991, 20, 119-123.
81. Camobreco, V. J.; Richards, B. K.; Steenhuis, T. S.; Peverly, J. H.; McBride, M. B.: Movement of heavy metals through undisturbed and homogenized soil columns. Soil Science. 1996, 161, 740-750.

82. Sidle, R. C.; Kardos, L.: Transport of heavy metals in a sludge-treated forested area. J. of Environ. Quality. 1977, 6, 431-437 